\title{
State of the art of language learning design using mobile technology: sample apps and some critical reflection
}

\author{
Elena Bárcena ${ }^{1}$, Timothy Read ${ }^{1}$, Joshua Underwood ${ }^{2}$, \\ Hiroyuki Obari $^{3}$, Diana Cojocnean ${ }^{4}$, Toshiko Koyama ${ }^{5}$, \\ Antonio Pareja-Lora ${ }^{6}$, Cristina Calle ${ }^{7}$, Lourdes Pomposo ${ }^{7}$, \\ Noa Talaván ${ }^{1}$, José Ávila-Cabrera ${ }^{1}$, Ana Ibañez ${ }^{1}$, Anna Vermeulen ${ }^{8}$, \\ María Jordano ${ }^{1}$, Jorge Arús-Hita ${ }^{6}$, Pilar Rodríguez ${ }^{1}$, \\ María Dolores Castrillo ${ }^{1}$, Andras Kétyi ${ }^{9}$, Jaime Selwood ${ }^{10}$, \\ Mark Gaved $^{11}$, and Agnes Kukulska-Hulme ${ }^{11}$
}

\begin{abstract}
In this paper, experiences from different research groups illustrate the state-of-the-art of Mobile Assisted Language Learning (henceforth, MALL) in formal and non-formal education. These research samples represent recent and on-going progress made in the field of MALL at an international level and offer encouragement for practitioners who are trying to incorporate these approaches into mainline second language teaching. Furthermore, researchers interested in the field
\end{abstract}

1. UNED, Spain; mbarcena@flog.uned.es; tread@1si.uned.es; ntalavan@flog.uned.es; javila@flog.uned.es; aibanez@flog.uned.es; mjordano@flog.uned.es; prodriquez@flog.uned.es; mcastrillo@flog.uned.es

2. British Council, Spain; josh.underwood@gmail.com

3. Aoyama Gakuin University, Japan; obari119@gmail.com

4. University of Exeter, UK; diana.cojocnean@gmail.com

5. Osaka Ohtani University, Japan; tokkokoyama@gmail.com

6. UCM, Spain; apareja@sip.ucm.es; jarus@filol.ucm.es

7. Universidad Camilo José Cela, Spain: kriscalle@gmail.com; loupomposo@madrid.uned.es

8. Ghent University, Belgium; anna.vermeulen@ugent.be

9. Budapest Business School, Hungary; ketyi.andras@kkk.bgf.hu

10. Hiroshima University, Japan; jselwood@hiroshima-u.ac.jp

11. The Open University, UK; mark.gaved@open.ac.uk; agnes.kukulska-hulme@open.ac.uk

How to cite this article: Bárcena, E. et al. (2015). State of the art of language learning design using mobile technology: sample apps and some critical reflection. In F. Helm, L. Bradley, M. Guarda, \& S. Thouësny (Eds), Critical CALL - Proceedings of the 2015 EUROCALL Conference, Padova, Italy (pp. 36-43). Dublin: Researchpublishing.net. http://dx.doi.org/10.14705/rpnet.2015.000307 
can see that the work presented here exemplifies how fertile it is, which should hopefully serve as motivation to undertake new studies to move the state-of-the-art further on.

Keywords: MALL, apps for smartphones and tablets, lifelong learning, blended learning, autonomous learning, self-regulation, flipped lessons, locationbased learning, podcasting, audio description, beacons, Moodle, Busuu, oral comprehension, vocabulary acquisition, business English.

\section{Introduction}

Eight years after the introduction of the first globally popular smartphone, mobile technology continues to influence how foreign languages are taught and studied. Mobile hand-held devices, namely smartphones and tablets, offer a highly convenient way to integrate digital technology as part of the languagelearning process. The huge growth in ownership of such devices amongst the student population means that access to online content, especially through mobile applications (apps), has harnessed their potential for language learning. In 2015, with approximately 1.5 million different apps available to download via app stores such as Google Play and iTunes, institutions, instructors and students have the opportunity to apply new identified forms of MALL that are being discovered in the research community. Hence, in this paper, experiences from different international research groups illustrate the state-of-the-art of MALL in formal and non-formal education.

\section{State-of-the-art of MALL in formal and non-formal education}

Selwood (2015) has undertaken an analysis of apps that were successful to different extents within the classroom. In addition, a language-learning app designed by the author has given rise to insights into the development and publishing of such tools. Underwood (2014) has integrated language learning design tasks, processes and frameworks in courses for teenage EFL learners and for teacher training (van Lier, 2007). These courses aimed to help participants design their own MALL activities. Analysis of such activities and reflection on the process and outcomes of both kinds of courses suggested some key tensions in MALL. In particular, Underwood (2014) has highlighted participants' varying attitudes to mobile devices for learning (distracter vs. enabler); the need for self-regulation in MALL vs. the use of mobile technology to support self-regulation; and the potential for mobile devices to support regular and repeated fleeting engagement in learning vs. deep immersive 
learning. These tensions together with reflection on the courses themselves suggested ways in which the design frameworks used could be improved and better integrated with assessment frameworks and activities beyond the time frame and physical location of the course, in order to produce more transferable and durable impacts on participants' learning practices.

In contrast to traditional learning, Obari has claimed the flipped classroom is a unique educational environment which is quickly gaining in popularity among educators worldwide (Obari, Kojima, \& Itahashi, 2010; Gualtieri, 2011). In a flipped classroom, students learn the course contents (via online videos, materials, etc.) before coming to class, and spend the bulk of classroom time asking questions and engaging in interactive discussions. An experimental group was exposed to flipped lessons using a variety of materials such as the 'Lecture Ready II' digital text designed for iPad, COOORI e-learning software for learning words and phrases related to the digital text, ATR CALL Brix e-Learning, Newton e-Learning, and TED Talks. An assessment of pre-treatment and post-treatment TOEIC scores and the OPIc computer-based speaking test resulted in a considerable improvement of the flipped classroom group. Post-questionnaires administered to these students indicated that they were more satisfied and motivated by the blended learning environment incorporating MALL.

Cojocnean's work has focused on high school students' use of vocabulary learning strategies in a digital context which had a mixed methodology, including a number of focus group discussions and a post-questionnaire (Palalas, 2011; Pegrum, 2014). The results indicated that most participants had a low usage of digital tools and also moderate attitudes towards the use of MALL and CALL tools in their vocabulary learning. As to students' views on MALL tools, they preferred those that enable incidental vocabulary learning as dedicated apps were not seen to be challenging enough, partially because words appeared out of context. The participants reported that they viewed apps as sources of entertainment rather than learning and that they could not focus on a single activity while using the app. Likewise, the participants explained that in their schools there was not a MALL or CALL culture. Cojocnean concluded that as long as schools do not promote the use of MALL tools in the lessons and teachers do not know exactly how to make use of MALL and CALL in the classroom, there will be fewer chances for students to use mobile technology in their learning outside the classroom.

Koyama's ongoing project aims to explore a dictionary interface while making a comparison of dictionary apps on smartphones and tablets. The project was designed on the basis of the findings of Koyama (2014), which indicates that the 
participants preferred a physical keyboard equipped with a pocket E-dictionary even though the learning effects seemed to be the same between both dictionaries. The aim of the present study was, therefore, to compare a similar dictionary interface. The participants were university students. In the first session, learners' look-up behavior on a smartphone and tablet apps were compared. They were assigned a word definition and a reading comprehension task with their respective types of dictionary. The time that they needed for the tasks, the number of lookups, and the quiz scores were verified. In the second session, a recognition test was conducted to investigate how the looked-up words were retained. No differences were found in the time needed and the number of the looked-up words. However, the rate of recognition was higher when they used smartphonebased dictionaries. Additionally, rich feedback was obtained concerning mobile dictionary interface from the participants. Like the participants' feedback in Koyama (2014), all the students insisted that elementary school students should not use smartphones when looking up words. It was inferred, therefore, that mobile dictionaries should be selected according to learners' ages based upon these findings.

The VIOLIN app (VIdeOs for LIsteNing), created by Talaván and Ávila-Cabrera, offers both teachers and students an audiovisual tool for the development of aural skills (Talaván \& Ávila-Cabrera, 2015). VIOLIN resorts to the improvement of aural comprehension through audiovisual reception and content-based activities. This app includes a selection of a series of short video clips, based on three features: they are entertaining, self-contained and context-independent. Users can view the video clips, taken from a well-known TV series, independently and every activity is divided into five stages for which users are briefed. Such activities are presented by following four consecutive steps: (1) selective, (2) intensive, (3) global listening, and (4) self-evaluation.

Pareja, Calle and Pomposo produced BusinessApp with both a general and a specific purpose: to help improve its users' oral skills in English and to help them put these oral skills into practice to create and perform effective business presentations (Calle, Pomposo, \& Pareja-Lora, 2015; Pareja-Lora, Calle, \& Pomposo, 2015). BusinessApp has been developed to be used by professional workers who need to make business presentations in English; and students in general who have to make presentations in any area (and in any language). From a more technical point of view, BusinessApp is a pedagogically and linguistically-based didactic unit previously created by the authors. It contains a series of modules, each one accompanied by examples and exercises which are automatically corrected in order to facilitate autonomous learning. 
Ibañez, Vermeulen and Jordano (2015, in press a, in press b) produced VISP (VIdeos for SPeaking), a MALL app that is based on applying audio description (a mode of audio visual translation which consists of orally describing what appears on the screen) to help users practise their speaking abilities. This is especially the case for their lexical and phraseological competences, given the fact that the time audio describers have to narrate what they see on the screen is very limited and they have to use accurate vocabulary in an idiomatic way. This app was tested with several students of English as a foreign language in UNED (Spain) and Ghent University (Belgium). VISP 2.0 has been updated in the light of the relevant data derived from pre and post-questionnaires (included in the app) and the first recordings received from the users, which constitute the essential part of VISP. This app is also framed within the task-based learning and the transferable skills approach, which are considered by the authors to provide adequate and solid methodologies for the development of users' language skills, following the Common European Framework of References for Languages.

Arús-Hita and Rodríguez Arancón (2015) have produced the design for a mobile application: Eating out, a Moodle-based EFL self-education digital learning resource. An experiment was carried out with a group of EFL university students at the Universidad Complutense de Madrid (Spain) during a semester, some of them using a PC, others a mobile device. At the end of the semester, a questionnaire was made available to them on Moodle. They answered a number of questions on pedagogical and technical aspects of their experience with Eating out. The contents of the post-questionnaire were based on a quality guide and rubric previously used in our work on the evaluation of EFL apps. The evaluation of Eating out by the students allowed the authors to obtain valuable information that may help to improve this learning resource as well as future apps to be developed. An additional aspect of the post-questionnaire was that the authors could compare the experiences of students working on a computer and a mobile device. They could thus see whether the learning resource was as valid for MALL as it was for CALL, and derive implications as to whether a single resource could be used for both types of teaching.

Bárcena and Read produced the Audio News Trainer for English (ANT), an oral comprehension app developed for the pedagogically guided use of audio news podcasts (Read \& Bárcena, in press; Read, Bárcena, \& Kukulska-Hulme, in press). Two versions of the app were produced, the difference being the use of social media as a way to motivate students and make them proactive. Research was undertaken with the app to study its motivational properties (and whether 
news could be an effective domain for listening comprehension training), and whether using the app could modify learning habits and help to establish appropriate metacognitive strategies. Other emergent features of using this app also became apparent as the experiment progressed.

Kétyi (2013) has looked for a language learning strategy involving mobile devices. The main idea was that, if the mobile devices could be integrated in the language teaching practice, students at the Budapest Business School could gain valuable additional learning time outside the classroom and therefore they could improve their language learning accordingly. The mobile language learning app chosen for the project was busuu and the participants were students of four different foreign languages (German, English, Spanish, Italian). It was found that busuu and the similar language learning apps were still new and unknown for the students (only one of them had used busuu before). The use of busuu was straightforward and it worked smoothly on the students' devices. During the study, the research group improved their performance according to the language test results while the control group did not. Analyzing gender data, it was found that female students performed at the post measurement better than male ones. However, according to the students, busuu is not an ultimate language learning tool, since it does not improve every language skill equally. It primarily helps in vocabulary acquisition.

Gaved and Kukulska-Hulme have explored location-triggered mobile language learning accessed through smartphones (Gaved \& Peasgood, 2015; Gaved, Greenwood \& Peasgood, 2015; Kukulska-Hulme et al., 2015). They have investigated how an emerging technology, Bluetooth beacons, might trigger location-specific learning activities to support informal and incidental learning. On entering an area which has a beacon, a notification (similar to an SMS) is triggered on the learner's phone and invites them to view the learning activity, which can be stored either on a remote website, or locally on the phone to allow access in places without network connectivity. Other location-triggered language learning approaches have been previously tried. However, they have faced the challenges of accuracy, performance indoors as well as outside, or the barrier of explicit and visible interaction with a triggering object in an area. This technology enabled identification of proximity to a place of interest, and yet allowed a user to engage with a learning activity discretely. The authors have also been considering ethical challenges that surround mobile language learning research focusing on locationbased activities: investigating issues around tracking of activities, privacy, and participants as co-researchers. They have recently carried out a pilot study with a series of scenarios across Milton Keynes (UK). 


\section{Conclusion}

In summary, the research presented above illustrates recent and ongoing progress made in the field of MALL at international level. This is intended to offer encouragement both for practitioners who are trying to incorporate these techniques into mainline second language teaching and students wishing to make use of this applied technology.

Furthermore, researchers interested in MALL can see that the recent and on-going work presented above exemplify how fertile and promising the field is. This article will hopefully act as a motivation for them to undertake new studies to move the state-of-the-art further on.

\section{References}

Arús-Hita, J., \& Rodríguez-Arancón, P. (2015) Autonomous learning resources for the teaching of EFL: what learners think, Encuentro, 23, 1-15.

Calle, C., Pomposo, L., \& Pareja-Lora, A. (2015). BusinessApp: Una aplicación para el aprendizaje del inglés mediante dispositivos móviles en el campo de los negocios. E-Aesla, 1. Retrieved from http://cvc.cervantes.es/lengua/eaesla/pdf/01/19.pdf

Gaved, M., Greenwood, R., \& Peasgood, A. (2015). Using and appropriating the smart city for community and capacity building amongst migrant language learners. In G. Avram, F. De Cindio \& V. Pipek (Eds.), Proceedings of the 7th International Conference on Communities and Technologies (pp. 63-72), University of Limerick.

Gaved, M., \& Peasgood, A. (2015). Location-based language learning for migrants in a smart city. In Proceedings of the 15th International Conference on Technology, Policy and Innovation (ICTPI'15), The Open University.

Gualtieri, M. (2011). Mobile app design best practices: when it comes to designing the mobile user experience (UX), context is kingonline article: Retrieved from http://www.forrester. com/rb/Research/mobile_app_design_best_practices/q/id/59132/t/2

Ibáñez A., Vermeulen, A., \& Jordano, M. (2015). Diseño y evaluación de VISP, una aplicación móvil para la práctica de la competencia oral. In A. Pareja-Lora, M.D. Castrillo \& M. Jordano (Eds.), El aprendizaje a distancia de lenguas extranjeras mediante tecnología móvil: del podcasting a los MOOC. RIED: Revista Iberoamericana de Educación Superior a Distancia.

Ibáñez, A., Vermeulen, A., \& Jordano, M. (in press a). Using audio description techniques to improve B1 EFL students' oral competence in MALL: methodological preliminaries. Proceedings of the 2014 TISLID Conference, London: Macmillan.

Ibáñez, A., Vermeulen, A., \& Jordano, M. (in press b). VISP, an enjoyable app to enhance idiomaticity in English. Proceedings of the XVIIth International CALL Research Conference:Task Design and CALL, University Pompeu Fabra. 
Kétyi, A. (2013). Using smart phones in language learning - A pilot study to turn CALL into MALL. In L. Bradley \& S. Thouësny (Eds.), 20 Years of EUROCALL: learning from the past, looking to the future. Proceedings of the 2013 EUROCALL Conference, University of Evora, (pp. 129-134). Dublin/Voillans: Research-publishing.net. doi:10.14705/rpnet.2013.000150

Koyama, T. (2014). The impact of smartphone dictionary apps on EFL learning. Poster presented at Eurocall 2014 Conference at the University of Groningen, the Netherlands.

Kukulska-Hulme, A., Gaved, M., Paletta, L., Scanlon, E., Jones, A., \& Brasher, A. (2015). Mobile incidental learning to support the inclusion of recent immigrants. Ubiquitous Learning: an international journal, 7(2), 9-21.

Lier, L. van. (2007). Action-based teaching, autonomy and identity. International Journal of Innovation in Language Learning and Teaching, 1(1), 46-65. doi:10.2167/illt42.0

Obari, H., Kojima, H., \& Itahashi, S. (2010). Empowering EFL learners to interact effectively in a blended learning environment. In Proceedings of World Conference on Educational Multimedia, Hypermedia and Telecommunications 2010 (pp. 3438-3447). Chesapeake, VA: AACE.

Palalas, A. (2011). Mobile-assisted language learning: designing for your students. In S. Thouësny \& L. Bradley (Eds.), Second language teaching and learning with technology: views of emergent researchers (pp. 71-94). Dublin: Research-publishing.net. doi:10.14705/ rpnet.2011.000007

Pareja-Lora, A., Calle, C., \& Pomposo, L. (2015). Aprendiendo a hacer presentaciones efectivas en inglés con BusinessApp. RIED. Revista Iberoamericana de Educación a Distancia (special issue: El aprendizaje de lenguas extranjeras mediante tecnología móvil en el contexto de la educación a distancia y combinada), 18(3).

Pegrum, M. (2014). Mobile learning: languages, literacies and cultures. Basingstoke: Palgrave Macmillan. doi:10.1057/9781137309815

Read, T., \& Bárcena, E. (in press). The development of oral comprehension via mobilebased social media and the role of e-leading students. In A. Palalas \& M. Ally (Eds.), The international handbook of mobile-assisted language learning. Beiing: China University Press.

Read, T., Bárcena, E., \& Kukulska-Hulme, A. (in press). Mobile and massive language learning. In E. Martin-Monje, I. Alorza \& B. García-Riaza (Eds.), Technology-enhanced language learning for specialized domains: practical applications and mobility. London: Routledge.

Selwood, J. (2015). Going paperless in the classroom with mobile devices: pitfalls and benefits. Hiroshima Studies in Language and Language Education, 18, 165-177.

Talaván, N., \& Ávila-Cabrera, J. J. (2015). Audiovisual reception and MALL: adapting technology to real needs. Porta Linguarum, 24, 33-46.

Underwood, J. (2014). Using iPads to help teens design their own activities. In Sake Jager, Linda Bradley, Estelle J. Meima, Sylvie Thouësny (Eds), CALL Design: Principles and Practice - Proceedings of the 2014 EUROCALL Conference, Groningen, The Netherlands (pp. 385390). Dublin Ireland: Research-publishing.net. doi:10.14705/rpnet.2014.000250 


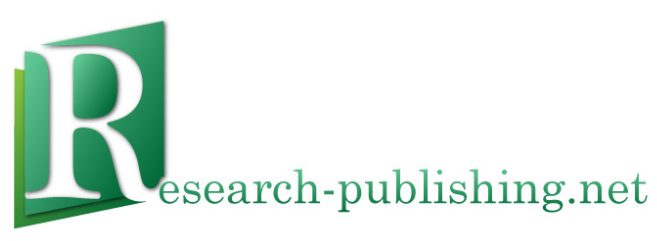

Published by Research-publishing.net, not-for-profit association Dublin, Ireland; info@research-publishing.net

(C) 2015 by Research-publishing.net (collective work)

(C) 2015 by Author (individual work)

Critical CALL - Proceedings of the 2015 EUROCALL Conference, Padova, Italy Edited by Francesca Helm, Linda Bradley, Marta Guarda, and Sylvie Thouësny

Rights: All articles in this collection are published under the Attribution-NonCommercial -NoDerivatives 4.0 International (CC BY-NC-ND 4.0) licence. Under this licence, the contents are freely available online (as PDF files) for anybody to read, download, copy, and redistribute provided that the author(s), editorial team, and publisher are properly cited. Commercial use and derivative works are, however, not permitted.

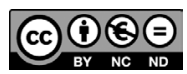

Disclaimer: Research-publishing.net does not take any responsibility for the content of the pages written by the authors of this book. The authors have recognised that the work described was not published before, or that it is not under consideration for publication elsewhere. While the information in this book are believed to be true and accurate on the date of its going to press, neither the editorial team, nor the publisher can accept any legal responsibility for any errors or omissions that may be made. The publisher makes no warranty, expressed or implied, with respect to the material contained herein. While Research-publishing.net is committed to publishing works of integrity, the words are the authors' alone.

Trademark notice: product or corporate names may be trademarks or registered trademarks, and are used only for identification and explanation without intent to infringe.

Copyrighted material: every effort has been made by the editorial team to trace copyright holders and to obtain their permission for the use of copyrighted material in this book. In the event of errors or omissions, please notify the publisher of any corrections that will need to be incorporated in future editions of this book.

Typeset by Research-publishing.net

Fonts used are licensed under a SIL Open Font License

ISBN13: 978-1-908416-28-5 (Paperback - Print on demand, black and white)

Print on demand technology is a high-quality, innovative and ecological printing method; with which the book is never 'out of stock' or 'out of print'.

ISBN13: 978-1-908416-29-2 (Ebook, PDF, colour)

ISBN13: 978-1-908416-30-8 (Ebook, EPUB, colour)

Legal deposit, Ireland: The National Library of Ireland, The Library of Trinity College, The Library of the University of Limerick, The Library of Dublin City University, The Library of NUI Cork, The Library of NUI Maynooth, The Library of University College Dublin, The Library of NUI Galway.

Legal deposit, United Kingdom: The British Library.

British Library Cataloguing-in-Publication Data.

A cataloguing record for this book is available from the British Library.

Legal deposit, France: Bibliothèque Nationale de France - Dépôt légal: décembre 2015. 